\title{
Comparison Study on The Competence of Employee and Non- Employee Students in STIE Indonesia Pontianak
}

\author{
Jumardi Budiman \\ Sekolah Tinggi Ilmu Ekonomi Indonesia Pontianak \\ jumardib@gmail.com
}

Keywords:

comparison, competence, employee and non employee students

\section{ABSTRACT}

The aim of this research was to know the difference level of employee students and nonemployee students competence in STIE Indonesia Pontianak. The research variables were viewed from 3 (three) aspects, they are cognitive, affective and psychomotor aspects. The method used in this research was quantitative comparative (Comparison study) with questionnaires as the tool of data collecting which were distributed to the 420 students as the research sample. The conclusion of this research was there were differences on cognitive and psychomotor aspects on employee and non employee students and there was no difference on affective aspect.

\section{INTRODUCTION}

The growth of economic and awareness in education level in West Borneo are the main factors of the increasing of people interest to continue thier study to the higher education level. The first option for them are state universities which grant high qualities and low in cost. Yet, the significantly increasing of people interest to make the state universities as their next education place is not adequate to the capacity available in the universities. This situation makes some of the students who failed to enter the state universities move in and enroll theirselves to the private universities in order to get their scholar degree as the asset for them for applying a job or improving their capacity at present job. Beside its limited capacity that available in the state universities, the flexibility study time as needed is another factor that makes private universities are chossen. Some private universities provide afternoon or evening class as their regular class. These classes are dominated by employees (private or civil servant) or the students who intend to have a job while studying.

This phenomenon also occurs in the private univesity where the researcher is lecturing, it is in STIE Pontianak which provides 2 (two) study programs they are Management (S-1) and Accounting (D-3). Based on the researcher's observation while lecturing, the morning regular classes are dominated by 
the students who just graduated from Senior High School that continue their study directly and they who have no part time job. The afternoon regular classes are dominated by employees (private or civil servant) who have finished their Senior High School several years ago. The main factor why the students choose this afternoon regular classes are: 1) the schedule of study time is representative (after working hours) ; 2) as profession demanding to have a scholar degree ;3) the willingness to improve their competences at work; and 4) wishing to get a better job after get scholar degree (as the result of interviewing some afternoon regular class students).

Despite, the employee students' intention to continue their study to a higher level is a great motivation, there are consequences that must be through by them for instance they need to be able to manage their time, energy and mind between job and study tasks. Some students of afternoon regular class did not fullfill the attendace requirements to take semester final examination due to failed in manage their time for job and study. This condition was so different with the morning regular class which mostly fullfill the minimum $80 \%$ of attendance.

Other differences that the researcher observed from the employee students in the afternoon and morning regular class, there are 3 (three) aspects: 1) cognitive aspect is the study achievement in GPA; 2) psychomotor aspect is students' activities at classroom; and 3) affective aspect is interest and attitude in learning process. The differences among these three aspects are guessed caused by several internal and external factors. This assumption is subjected to the research result of Nasution (2001), stated there is a relation between lecturing methods, learning skills, learning tools, and learning circumstances toward students' learning result. This is strengthen by Pujiadi (2007) that the students' learning result is influenced by some factors, they are intrinsic of the students itself, lecturing styles, study material contents, and study methods.

Practically, the lecturers apply different lecturing methods when they are lecturing afternoon regular class students which the physic and mental of the students must be depleted while working as the consideration. Besides, the internal factors are the skills and learning styles of employee students that focus more on problem based learning especially the problems that are related to their daily job. While on the morning regular class students (non employee), the lecturers focus more on theoritical comprehension by using lecturing methods that focused on students' activities.

Subjected to the phenomenon above, the researcher felt it is needed and crucial to conduct a research to know the difference level of employee students and non employee students competences based on cognitive, psychomotor, and affective aspects on STIE Indonesia Pontianak students.

\section{METHOD}

The research method used was quantitative comparative to measure the difference level of employee students and non employee students competences. The variables in this research were students' competences as cognitive (knowledge), affective (attitude) and psychomotor (skills). The subjects of this research were 752 students of STIE Indonesia Pontianak consisted of 303 morning regular class students and 449 afternoon regular class students. Due to the restrict amount of time and capacity, the researcher only took 420 students as the samples. The collecting sample technique used sampling quota which 210 morning regular class students and 210 afternoon regular class students. The data collecting technique used indirect communication technique with questionnaires as the tools of collecting data. The data gained was proceed by using SPSS program version 17.0 to know the differences levels among the research subjects. 


\section{RESULTS AND DISCUSSIONS}

\section{RESULTS}

\section{Result Of Cognitive Aspect Differences}

Tabel 1

Independent Sampel Test Of Cognitive Aspect

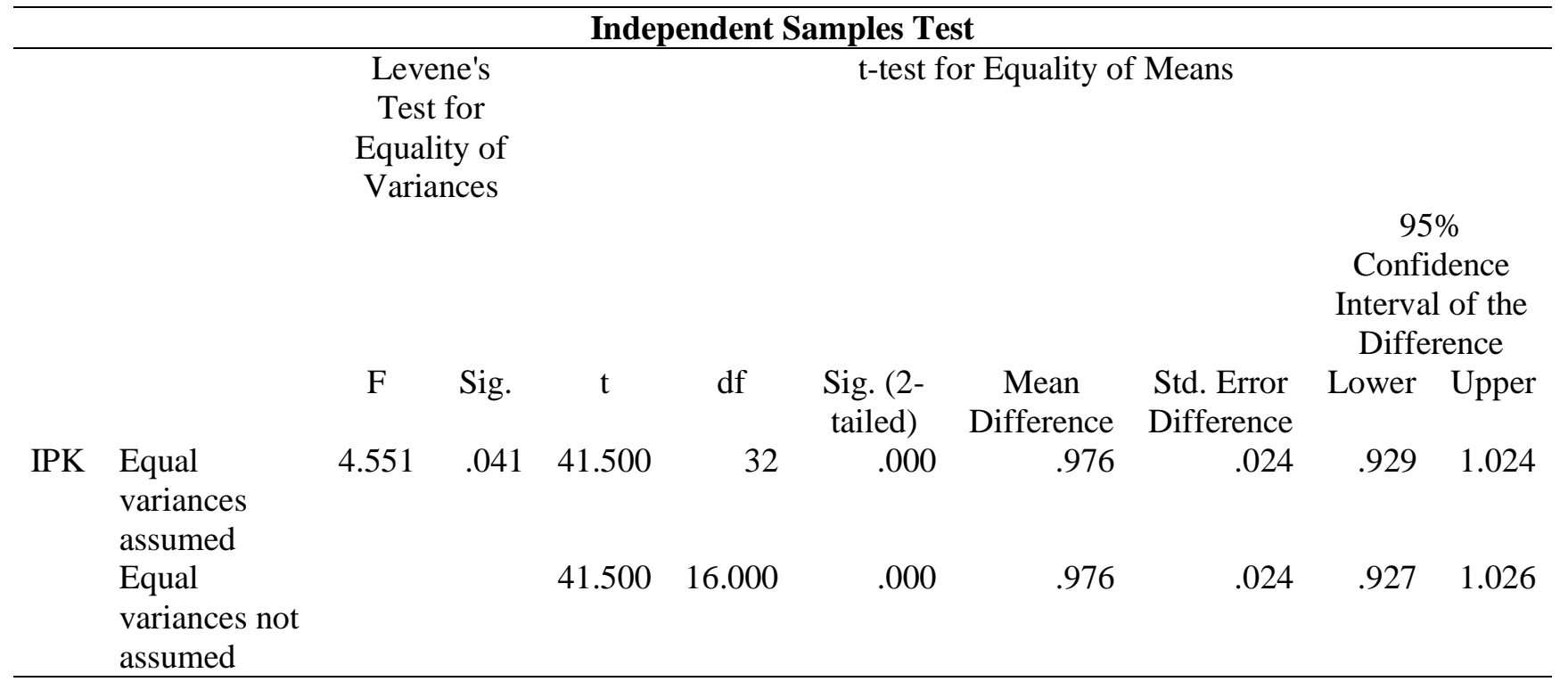

Based on the table above, it could be known that $\mathrm{t}$ test value was 41.50 and $\mathrm{t}$ table was 1.980 or $\mathrm{t}$ test $>\mathrm{t}$ table so it could be concluded that there was a cognitive aspect difference between employee students and non employee students. The significant score 0.041 (less than 0.05) so it could be stated that the differences level was significant.

\section{Result Of Affective Aspect Differences}

Tabel 2

Independent Sampel Test Of Affective Aspect

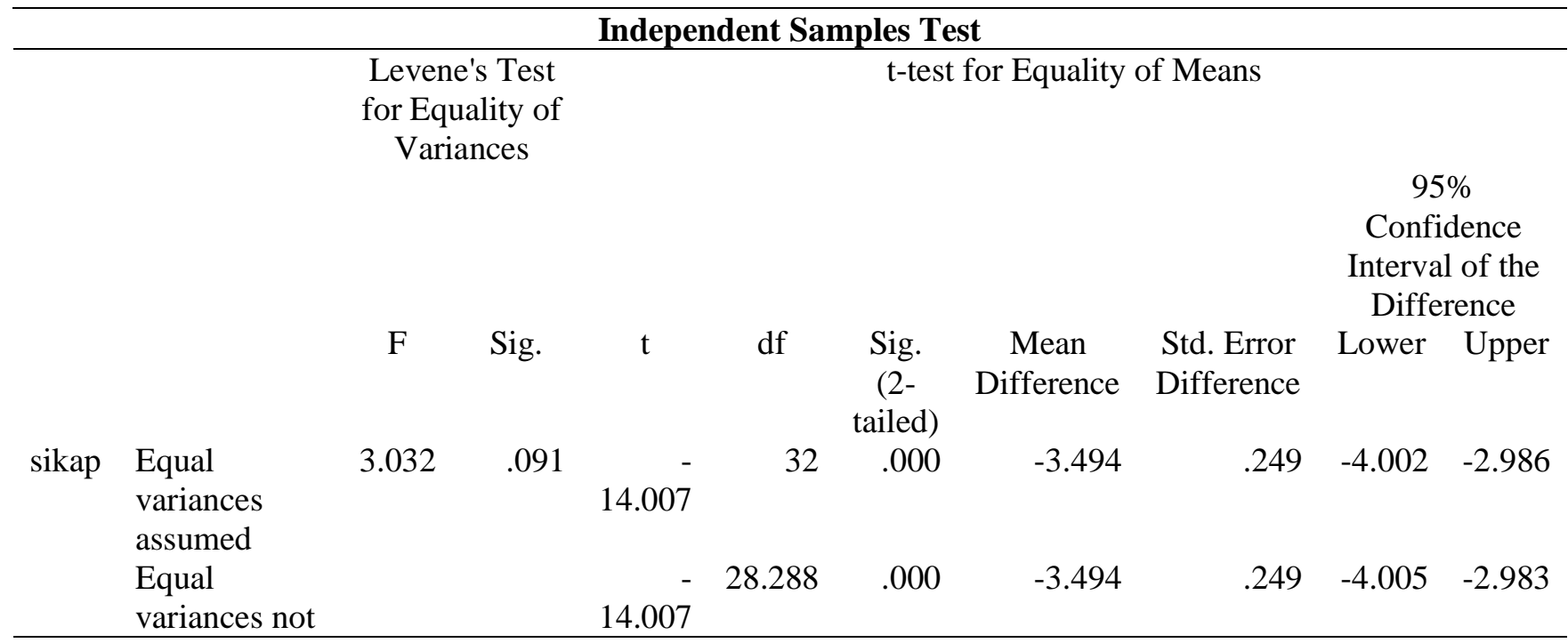


Based on the table above, it could be known that $t$ test value was -14.007 and $t$ table was 1.980 or $t$ test $<\mathrm{t}$ table so it could be concluded that there was no affective aspect differences between empoyee students and non employee students. The significant score was 0.091 (more than 0.05) so it could be stated that there was no significant differences.

\section{Result Of Psychomotor Aspect Differences}

Tabel 3

Independent Sampel Test Of Psychomotor Aspect

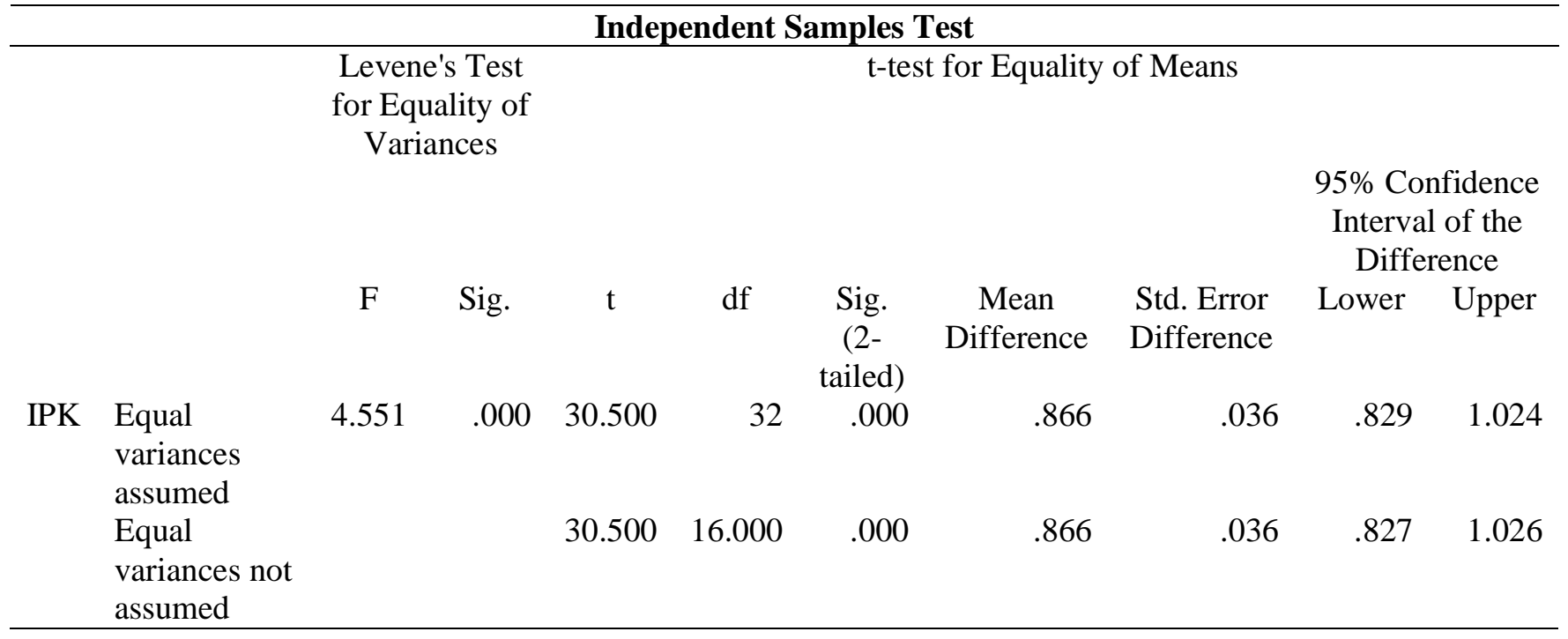

Based on the table above, it could be known that $\mathrm{t}$ test value was 30.500 and $\mathrm{t}$ table was 1.980 or $\mathrm{t}$ test $>\mathrm{t}$ table so it could be concluded that there was psychomotor aspect difference between empoyee students and non employee students. The significant score was 0.000 (less than 0.05 ) so it could be stated that the differences level was significant.

\section{DISCUSSION}

Based on the result of statistic calculation by testing the differences level of both independent groups above, it could be known that there was a significant difference between employee students who took afternoon regular class with non employee students who took morning regular class on cognitive and psychomotor aspects. Besides, there was no significant differences on affective aspect.

\section{Cognitive Aspect Differences}

Cognitive aspect is about students' ability to observe, watch, guess, pay attention and evaluate (Khairani, 2013:45). This aspect shows students' ability to comprehend all materials delivered in learning process at the classroom. Cognitive aspect is seen as the main aspect in learning process at formal education institution because it has benchmark on its assesing process. The students who have high GPA are representated as the students who definitely have high cognitive competence. This paradigm made employee students' GPA mostly lower than non employee students because the non employee students were more focus on GPA result while employee students focused on process of learning.

The non employee students who were attending morning class had the enough time in preparation befor class started and reviewing materials after class. Besides, they had spare time to add their knowledge by searching the additional literatures in library or internet. Mostly, employee students 
used their time to work, did not have enough time to prepare theirselves before class because after working they directly went to the classroom. Beside the factor of time, the condition of mind and physic of employee students that were spent for working also decreased their ability in comprehending the theoritical materials. It was different to non employee students who just spent their energy and mind to learn the materials and complete the tasks.

Yet, there wad one difference point of view (paradigm) in learning process between employee and non employee students. Employee students only paid the attention on materials that were directly related to their position and tasks at work place so they tended to be more focus on the materials that was important to their career development and denied the irrelevant materials otherwise. It was different to the non employee students who accepted the whole materials taught by lecturer. The impact of these difference paradigms were obvious where the scores for employee students were not prevalent (the job- relevant subjects are higher than the irrelevant ones) while the whole subject scores were prevalent for the non employee students.

\section{Affective Aspect Differences}

The result of calculation above showed there was no significant difference between employee students and non employee students. It indicated on the Affective aspect both employee and non employee students have good attitude in learning process, although the researcher thought it caused by different things. The good attitude that was showed by non employee students were motivated by the feelings to get good responses from the lecturers and afraid of the punishment given if they have bad attitude. For employee students, it was as the result of their at work place attitude that they must respect their bosses.

\section{Psychomotor Aspect Differences}

The result of research on Psychomotor aspect difference which was representated as learning process activities showed significant differences between employee and non employee students. On non employee students, learning activities at classroom were more interactive because there was a good communication occured between the students and lecturers. Their responses on the materials dellivered were higher that made learning atmosphere became attractive and fun. It made many lecturers varied in using lecturing methods to non employee students. For employee students, the learning process tended to be passive and one way (lecturer centered). It was normal because generally they did not have enough time to take a rest between working and studying. As consequences, they tended to be silent and lack of responses at materials delivering process. This passive attitude made the lecturer difficult to know indicator achievement of materials delivered because when they were asked to questioning or give opinion the students did no response.

\section{CONCLUSION AND SUGGESTION}

\section{CONCLUSION}

Based on research result, so there were some conclusions as follows: 1) There was significant difference of cognitive aspect between employee and non employee students in STIE Indonesia Pontianak which was proved by $t$ test $>t$ table $(41.50>1.980) ; 2)$ there was no significant difference of affective aspect between employee and non employee students in STIE Indonesia Pontianak which was proved by $\mathrm{t}$ test $<\mathrm{t}$ table $(-14.007<1.980) ; 3)$ there was significant difference of psychomotor aspect between employee and non employee students in STIE Indonesia Pontianak which was proved by $\mathrm{t}$ test $>\mathrm{t}$ table $(30.500>1.980)$. 


\section{SUGGESTION}

Based on conclusion above, the researcher could suggest several things as follows: 1) the lecturers should be able to apply learning methods that suitable to the capacity of employee and non employee students ; 2) the lecturers should be able to give priority on learning materials that are relevant to the employee students' need; 3) the employee students should be more active in learning process at classroom and able to improve study achievement by integrating the work place experiences with materials delivered at campus.

\section{REFERENCES}

Pujadi, Arko. 2007. Faktor-Faktor Yang Mempengaruhi Hasil Belajar Mahasiswa: Studi Kasus Pada Fakultas Ekonomi Universitas Bunda Mulia. Jurnal Bisnis Dan Manajemen. Vol. 3. No 2.

Nasution Farid. 2001. Hubungan Metode Mengajar Dosen, Keterampilan Belajar, Sarana Belajar Dan Lingkungan Belajar Dengan Prestasi Belajar Mahasiswa. Jurnal Ilmu Pendidikan. Jilid 8. No 1.

Khairani, Makmun. 2013. Psikologi Belajar. Yogyakarta: Aswaja Pressindo. 